NBER WORKING PAPER SERIES

\title{
THE ANNUITIZATION OF AMERICANS' \\ RESOURCES: A COHORT ANALYSIS
}

\author{
Alan J. Auerbach \\ Jagadeesh Gokhale \\ Laurence J. Kotlikoff \\ John Sabelhaus \\ David N. Weil
}

Working Paper No. 5089

\section{NATIONAL BUREAU OF ECONOMIC RESEARCH 1050 Massachusetts Avenue \\ Cambridge, MA 02138 \\ April 1995}

We thank Douglas Gale and Mark Schweitzer for helpful comments, Felicitie Bell for providing us with critical data on the United States' population projections, and Jean McIntire for excellent research assistance. Auerbach and Kotlikoff also thank the National Institute of Aging for research support. This paper is part of NBER's research program in Public Economics. Any opinions expressed are those of the authors and not those of the National Bureau of Economic Research.

() 1995 by Alan J. Auerbach, Jagadeesh Gokhale, Laurence J. Kotlikoff, John Sabelhaus and David N. Weil. All rights reserved. Short sections of text, not to exceed two paragraphs, may be quoted without explicit permission provided that full credit, including $(\mathcal{C}$ notice, is given to the source. 


\title{
THE ANNUITIZATION OF AMERICANS' \\ RESOURCES: A COHORT ANALYSIS
}

\begin{abstract}
This paper constructs a unique cohort data set to study the changes since 1960 in the share of Americans' resources that are annuitized. Understanding these changes is important because the larger this share, the more cohorts are likely to consume and the less they are likely to bequeath. Hence, the degree of annuitization affects national saving as well as the transmission of inequality over time.

Our findings are striking. Although the annuitized share of resources of younger Americans declined slightly between 1960 and 1990, it increased dramatically for older Americans. It doubled for older men and quadrupled for older women. Since the elderly have much higher mortality probabilities than do the young, their degree of annuitization is much more important for aggregate bequests and saving. According to our estimates, aggregate U.S. bequests would now be 66 percent larger had the post-1960 increase in annuitization not occurred. In addition, U.S. national saving would likely be substantially larger than is currently the case.
\end{abstract}

Alan J. Auerbach

Department of Economics

549 Evans Hall

University of California

Berkeley, CA 94720-3880

and NBER

Laurence J. Kotlikoff

Department of Economics

Boston University

370 Bay State Road, 3rd Floor

Boston, MA 02215

and NBER

David N. Weil

Department of Economics

Brown University

Box B

Providence, RI 02912

and NBER
Jagadeesh Gokhale

Federal Reserve Bank of Cleveland

1455 East 6th St.

Cleveland, OH 44101

John Sabelhaus

The Urban Institute

2100 M St., NW

Washington, DC 20037 


\section{Introduction}

This paper constructs a unique cohort data set to examine changes since 1960 in the share of Americans' resources that are annuitized (cannot be bequeathed). Understanding these changes is important. Generations whose resources are more annuitized will consume more and bequeath less to their children and others. ${ }^{1}$ This has implications for national saving as well as the intergenerational transmission of inequality.

Auerbach, Kotlikoff, and Weil (1992) report dramatic increases between 1962 and 1983 in the annuitization of elderly Americans' resources. Their study relies on two cross-section surveys, the 1962 and 1983 Surveys of Consumer Finances. The nature of these data forced the authors to impute many of the future annuity streams available to survey respondents, including labor earnings, Social Security benefits, and private pension income. They were also forced to exclude from the analysis the large medical annuities provided by Medicare and Medicaid.

This study takes a different approach. Rather than estimate the annuities of individual households, it considers the annuities of individual cohorts alive between 1960 and 1990. Specifically, it uses cross-section surveys to distribute to cohorts annual aggregate flows of income reported in the National Income and Product Account (NIPA) and other sources. Although this approach cannot address the interesting intracohort distribution issues considered in Auerbach et. al. (1993), it offers a potentially more accurate and comprehensive method of assessing the overall degree of annuitization among Americans.

Our findings are striking. Across all American males, the annuitized share of resources remained roughly constant between 1960 and 1990. For

${ }^{1}$ In this paper a 'generation' refers to persons of a given sex born in the same year. 
females it rose from a third to over one half. Moreover, among elderly Americans (age 65 and over), the annuitized resource share rose from 23 to 51 percent for men and from 13 to 54 percent for women. Without this increase in the degree of annuitization, U.S. aggregate bequests would be an estimated 66 percent larger. Although the precise impact on the consumption of the elderly of their increased annuitization is unclear, it appears to be substantial. Indeed, it appears capable of explaining a significant fraction of the decline in U.S. national saving.

Section II provides some background to this study. It defines annuitized and nonannuitized resources, considers some general indicators of the increase in annuitization, and discusses how increased annuitization can affect national saving. Section III outlines the methods used for estimating the annuitized and nonannuitized components of resources. Section IV describes our data sources. Section $V$ presents our findings and explores their implications. Finally, Section VI summarizes the results and draws conclusions.

\section{Background}

Annuities are income flows that are contingent upon their owner's survival. ${ }^{2}$ Examples include Social Security benefits, private and public pension benefits, government-provided health-care benefits, and labor earnings. Government transfer payments in the form of Social Security, Medicare, and Medicaid constitute a significant and growing portion of U.S. annuities. These transfer payments have grown from less than 1 percent of GDP in the mid-1950s to over 9 percent today. Pension benefits have also

2 Some annuities are contingent on other factors as well, such as the need for medical services. 
increased faster than GDP. In 1960 pensions totaled 1.7 percent of GDP. Today they total more than 5.4 percent.

Not all annuities are positive. Future tax payments are examples of negative annuities. In recent decades, U.S. taxes have also grown relative to GDP. Another factor that has lowered annuitization is the reduction in annuitized labor income associated with the trend toward early retirement. In $1960,33.1$ percent of elderly males (those aged 65 or more) and 10.8 percent of elderly females participated in the labor force. The corresponding 1992 percentages are 16.1 and 8.3 percent.

The public can also reduce its effective degree of annuitization by purchasing life insurance. As Yaari (1965) pointed out, the purchase of life insurance is equivalent to the sale of an annuity. Cohorts that do not offset increases in their annuitization through increased life insurance purchase are likely to bequeath less and consume more than would otherwise be the case. Davies (1981), Abel (1985), and Kotlikoff et. al. (1986) present simulations of the effects of introducing annuities in life-cycle economies. In their models agents have no bequest motive and, consequently, do not offset increased annuitization by buying more life insurance. The ability to transform their net worth (or to have it transformed) into annuities permits these agents to stop worrying about outliving their resources when they are old and to consume more. Each of these studies suggests that a significant increase in annuitization will be associated with a substantial decline in both national saving and aggregate bequests as well as a significant increase in the relative consumption of the elderly.

In the United States the increase in annuitization, which is documented below, has coincided with both a dramatic decline in national saving and a 
dramatic increase in the relative consumption of the elderly. Since 1980 the U.S. net national saving rate has averaged 4.1 percent, compared with 9.1 percent in the 1950s and 1960s, and 8.5 percent in the 1970s. In this decade the net national saving rate has averaged only 2.5 percent. A comparison of the 1960-61, 1972-73, 1984-86, and 1987-90 BLS Consumer Expenditure Surveys shows an equally remarkable rise in elderly persons' relative consumption. Chart 1 presents indices of average consumption by age for each of the four periods. ${ }^{3}$ For each period, the average consumption of 40 -year-olds is normalized to 1 .

As the chart indicates, the age-consumption profiles for later years are tilted upward compared to those for earlier years, indicating a rise over time in the relative consumption of the elderly. Table 1 reports the ratios of average levels of consumption of 70-year-old males and females to those of 30year-old males and females for each of the four periods. It shows that 70year-olds in 1960 consumed about two-thirds the amount consumed by 30-yearolds in 1960, whereas their consumption now exceeds that of 30-year-olds.

The increase in the annuitization of the elderly is certainly not the only, nor necessarily the most important, explanation for the increase in their relative consumption and the concomitant decline in national saving. Indeed, much of the explanation for these outcomes appears to lie in the

3 The source for this chart as well as Table 1 is Gokhale, Kotlikoff, and Sabelhaus (1994). Their study describes their method of allocating household consumption to the adults residing in the households interviewed in the various Consumer Expenditure Surveys. It also describes their methods of allocating by age and sex those components of household consumption expenditure included in the National Income and Product Accounts but excluded in the Consumer Expenditure Surveys. Examples of such components include imputed rent and medical care. The calculated average values of consumption by age and sex used in this chart and Table 1 are benchmarked on a component by component basis against the National Income Accounts totals of household expenditures for the various years in question. 
government's massive transfers to the elderly, which have raised their incomes relative to those of young people (see Boskin, Knetter, and Kotlikoff (1985) and Gokhale, Kotlikoff, and Sabelhaus (1994)).

\section{A Simple Model of the Effects of Annuitization ${ }^{4}$}

Analysis of the steady state of the following simple two-period lifecycle model makes clear the theoretical argument connecting increased annuitization to the decline in bequests and national saving: Agents live for two periods. They work full time when young (earning $W$ ) and consume $C_{y}$ when young and $\mathrm{C}_{\mathrm{o}}$ when old. Population is stationary, and the size of each cohort is normalized to unity. Each agent survives with probability (1-p) to old age. There is no private annuities market. However, the government provides annuities by taxing each cohort $T$ when young and returning this amount with interest to surviving members of the cohort when they are old. Since there are (1-p) survivors in each cohort, each survivor receives an annuity of $\mathrm{T}(1+\mathrm{r}) /(1-\mathrm{p})$, where $\mathrm{r}$ is the real interest rate.

If $T$ does not exhaust private saving, those who die prior to their last period of life will leave a bequest. Assuming bequests are divided equally among the young, the bequest received per young person is $\mathrm{pB}$, where $\mathrm{p}$ is the fraction of each cohort that dies prior to old age and $B$ is the bequest made per decedent.

At the beginning of any period (before anyone has died), total wealth in the economy, $K$, equals the sum of private wealth of the elderly plus the wealth held by the government. The wealth held by the government is just $\mathrm{T}$ -

4 This model is also presented in Auerbach et. al. (1992). 
the aggregate tax payments of each generation. Private wealth of the elderly can be traced to their saving when young, $W+p B-T-C_{y}$. Total wealth is just this sum plus $T$, so

$$
\mathrm{K}=\mathrm{W}+\mathrm{pB}-\mathrm{C}_{\mathrm{y}}
$$

For those leaving bequests, we have

$$
B=\left(W+p B-T-C_{y}\right)(1+r)
$$

For those agents who survive to old age, their consumption, $C_{0}$, is given by

$$
C_{0}=\left(W+p B-T-C_{y}\right)(1+r)+\frac{T(1+r)}{(1-p)}
$$

where the first term on the right-hand-side of (3) represents principal plus interest on private savings, and the second term is the government's annuity payment to survivors. We close the model by assuming that agents maximize an expected time-separable, homothetic utility function over consumption when young and old, given by

$$
U=u\left(C_{y}\right)+(1-p) \alpha u\left(C_{o}\right)
$$

where $\alpha$ is the time preference parameter. Maximization of utility subject to the budget constraint given in (3) implies that consumption when old is proportional to consumption when young, i.e.,

$$
\mathrm{C}_{\mathrm{o}}=\theta \mathrm{C}_{\mathrm{y}}
$$


where the factor of proportionality, $\theta$, depends on $\alpha, r$, and $p .5$

The above equations imply

$$
K=\frac{W-p T(1+r)[1+1 / \theta(1-p)]}{1-(1+r) / \theta-p(1+r)}
$$

According to equation (6), aggregate wealth is a decreasing function of $T$, the amount of saving which is annuitized by the government. The intuition for this result is clear from equations (1)-(3) and (5). According to (1) and (2), raising $\mathrm{T}$ lowers the steady-state level of bequests as well as the steady-state capital stock ignoring induced changes in consumption when young. If consumption when young were to fall as much as inheritances received when young ( $\mathrm{pB})$, aggregate wealth would remain unchanged. But, according to equations (3) and (5), consumption when young falls by less than $\mathrm{pB}$ for two reasons. First, the propensity to consume when young is less than unity. Second, the annuity provided by the government increases the amount each generation can afford to consume over its 1 ifetime because it reduces undesired bequests. 6

In our model agents have no interest in leaving bequests and, therefore, no interest in purchasing life insurance. As Yaari (1965) first demonstrated, the purchase of term life insurance is equivalent to the sale of an annuity. If we modified our model to include a bequest motive and the voluntary

5 In this model we are assuming that one cannot purchase annuities at the margin from private insurance companies. Allowing for such purchases would change the value of $\theta$.

6 Note that the reduction in aggregate wealth arising here is not, as in Feldstein (1974), the result of the government directly transferring resources from the young to the old, but rather the result of the government's indirectly assisting the old in reducing their transfers to the young. 
purchase of life insurance, we would find that government annuitization of the saving of the young would simply lead them to purchase more life insurance; i.e., the annuities purchased by the government would be immediately resold.

\section{Estimating Annultized and Nonannuitized Resources}

In this study we calculate the amounts of nonannuitized and annuitized resources for all male and female adult cohorts for the years 1960-1990. The components of annuitized resources are the present values of future labor earnings (human wealth), Social Security benefits, private and government employee pension benefits, government health care benefits, welfare benefits, and other government transfers, and, entering as negative annuities, the present values of future taxes. Taxes include labor and capital income taxes, indirect taxes, payroll taxes, and property and other taxes. Nonannuitized resources refer to holdings of net wealth.

The computation of cohorts' nonannuitized resources for each year between 1960 and 1990 involves distributing by age and sex each year's aggregate value of household net wealth. The computation of each annuitized resource component employs a common strategy. First, for each year, the national aggregate for a particular type of payment (or receipt) is distributed by age and sex according to the cross-section, age-sex relative profile that is applicable to that payment (or receipt). For example, aggregate 1965 Social Security benefits are distributed according to the age-sex relative profile for these benefits that prevailed in 1965. This yields estimates of the per capita amounts of the payment (or receipt) by age and sex for that year. The per capita annuity values for years after 1992 are estimated by either 1) distributing projected aggregate payments or receipts according to the latest 
available cross-section relative profile or 2) assuming that age- and sexspecific per capita values equal their respective values in 1992 or some later year except for an adjustment for productivity growth.

Second, for each generation in a given year $t$ (say, males born in 1966), the present value of all future per capita payments of a particular type (say, indirect tax payments) is computed by multiplying these future per capita payments by the generation's projected population in those years, discounting these values back to year $t$, and dividing the sum of the discounted values by the number of members of the generation alive in the base year. This method produces actuarially discounted present values of the particular receipt or payment for each generation alive in period $t$.

As an example of this method for calculating the different components of annuitized resources, consider the estimate of human wealth (HW). Our formula for human wealth in year $t$ of a person of $\operatorname{sex} x$ born in year $k, H W^{x}, k$, is

$$
H W_{t, k}^{x}=\frac{1}{P_{t, k}^{x}} \underset{s=t}{\sum} e_{s, k}^{-x} P_{s, k}^{x} R^{s-t}
$$

where $\overline{\mathbf{e}}_{s, k}$ stands for the average earnings in year $s$ of a member of the generation born in year $k$ and of $\operatorname{sex} x, \mathrm{P}_{s, k}$ is the population in year $s$ of the same generation, $R=1 /(1+r)$, where $r$ is the rate of interest, and $D$ is the maximum age of life. The calculation of $\bar{e}_{s, k}$ is given by

$$
\bar{e}_{s, k}^{x}=\frac{d_{s, k}^{x} E_{s}}{\sum_{s=t}^{k+D-t}\left(d_{s, k}^{m} P_{s, k}^{m}+d_{s, k}^{f} P_{s, k}^{f}\right)}
$$


In these equations $E_{s}$ is aggregate labor earnings in year $s, d^{x}, k$ is the ratio in year $s$ of the average earnings of the generation born in year $k$ of sex $x$ divided by the average earnings in year $s$ of our reference group those males who were age 40 in year s (i.e., those for whom $k=s-40$ ).

The construction of relative profiles by age and $\operatorname{sex}, d_{t, k}$, is described in equations (9) and (10):

$$
\bar{z}_{s, k}=\frac{\sum_{i=1}^{N_{k}^{x}} w_{i, s, k}^{x} z_{i, s, k}^{x}}{\sum_{i=1}^{N^{x}, k} w_{i, s, k}^{x}}
$$

$$
d_{s, k}^{x}=\frac{\bar{z}_{s, k}^{x}}{\bar{z}_{s, s-40}^{m}}
$$

In equation (9), $\bar{z}_{s, k}$ is the weighted average (across cohort members indexed by $i$ ) of labor income. $N^{x}, k$ is the number of observations in year $s$ of individuals of sex $x$ born in year $k, z_{s, k, i}$ is the wage and salary income of the $i^{\text {th }}$ individual of $\operatorname{sex} x$ in year $s$ who was born in year $k$, and $w^{x}, s, k$ is the person weight of this observation. Equation (10) shows the calculation in year $s$ of the average labor income of members of the generation with sex $x$ who were born in year $k$, relative to that of contemporaneous 40-year-old males.

\section{Data Sources}

The national aggregates used in our calculations come from the National Income and Product Accounts (NIPA), the Federal Reserve System's Flow of Funds 
(FOF), The American Council of Life Insurance (ACLI), the U.S. Census Bureau's Current Population Survey (CPS), and the Survey of Current Business (SCB). The sources for cross-section relative profiles are the CPS, the Survey of Income and Program Participation (SIPP), the Consumer Expenditure Survey (CES), the Survey of Consumer Finances (SCF), the Social Security Administration's Annual Statistical Supplement (SSASS), and the Health Care Financing Administration (HCFA). The computations also use the historic and projected population counts of the Social Security Administration (SSA). 7

The following is a more detailed description of our data sources and projections :

\section{Labor Income}

Aggregate labor income between 1960 and 1992 is calculated as labor's share of NIPA-reported national income. For each of these years, labor's share of national income is calculated under the assumption that its share of proprietorship income is the same as its share of national income. 8

Relative profiles of labor income by age and sex are calculated for each year between 1963 and 1992 using that year's CPS data on individual wages and salaries. Since these data are top-coded, we followed Shyrock and Seigel (1971) and estimated for each year the average wage and salary for top-coded observations. Their procedure uses the fact that the upper tail of the wage

7 SSA's projections are available through the year 2066. These projections were extended to the year 2200 by using SSA's mortality, fertility, and immigration assumptions for the year 2066.

8 Labor income's share of national income is $\alpha$, where $\alpha$ satisfies $C+$ $\alpha P I=\alpha N I$. In this equation, $C$ is compensation paid to employees, $P I$ is proprietorship income, and NI is national income. The calculated values of $\alpha$ are very stable over the years 1960-1992, ranging between 0.76 and 0.82 . 
and salary distribution can be well approximated by the Pareto distribution. Values of average wages for top-coded observations were calculated separately for males and females. These values were assigned to all top-coded observations before computing relative wage profiles. ${ }^{9}$ The annual profiles were smoothed over age by using a seven-year moving average of wages and salaries. The 1963 profiles are used to distribute aggregate labor income for years prior to 1963, and the 1992 profiles are applied for years after 1992. Per capita labor income for years beyond 1992 is projected under the assumption that, except for an adjustment for growth, cohorts of a given age and sex earn the same average labor income in future years as cohorts of that age and sex earned in 1992. For example, males who are age 50 in 1993 are assumed to earn the same amount on average, apart from an adjustment for growth, as males who were age 50 in 1992. The growth adjustment is 0.75 percent per year. Thus, the projected average earnings of males aged $50 \mathrm{in}$, say, 1994 equals the corresponding 1992 average for 50-year-old males multiplied by (1.0075).

Private and Government Employee Pensions, Workers Comp, and Veterans Benefits

This category includes four types of income - benefits from private pension plans, workers compensation, veterans benefits, and government employee pensions. Aggregate private pension benefits for the years 1960-1988 are the NIPA estimates reported in Park (1992). The NIPA estimates are based upon administrative reports and appear to be more reliable than other estimates that are based upon household surveys. Estimates of aggregate private pension benefits for 1989 through 1992 were derived by extrapolating the 1988 reported level of benefits using the 1984-1988 average annual growth

9 The small number of observations precluded separate estimation by age. 
rate of real aggregate private pension benefits. The aggregates for the other three types of benefits are reported in the SCB.

The relative profiles of the four types of income are computed from the March CPS. This survey contains information on income from a variety of sources including company or union pensions, workers compensation, veterans benefits, government employee pensions, and receipts from annuities and other regular contributions. Retirement, disability, and survivor benefits are included for each type of income.

Unfortunately, receipts from several sources of retirement income are aggregated into one variable in the CPS data. For example, in the 1980-88 data, private pension income is combined with income from government employee pensions (including federal, state, and local government pensions as well as military retirement pensions). Fortunately, the CPS specifies for each observation the different types of income that are being combined into the pension and other income variable. We use this information to identify, for each age and sex, those observations receiving only private pensions and those receiving only government employee pension recipiency. Next, we calculate, again by age and sex, the average values of the two types of income. Finally, we compute the ratio of average private pension income to the sum of the averages of income from private and government employee pensions. The ratio of average government employee pensions to average pension receipts for this age-sex category is one minus the ratio of average private pensions to average pension receipts. These two ratios are used to impute the values of private and government employee pensions for observations receiving both types of income. The computation of relative profiles for each year uses the age- and sex-specific cell averages of actual and imputed private and government 
employee pension income, smoothed across age using a seven year moving average .

Separate profiles were obtained for each of the four categories of income for each year between 1970 and 1992. The 1970 profiles were used to distribute the national aggregates of these payments in years prior to 1970 . For years after 1992, real average pension benefits at a given age and sex are set equal to their 1992 values adjusted for the assumed 0.75 percent rate of growth.

\section{Social Security Benefits}

Aggregate Social Security benefits between 1960 and 1992 are those reported by NIPA. Between 1993 and 2004 we use the Office of Management and Budget's (OMB) projections on a NIPA basis of Social Security benefits. Aggregate Social Security Old Age, Survivor, and Disability Insurance (OASDI) benefits after 2004 equal the 2004 aggregate adjusted for growth. The growth rates applied in this case are those embedded in a special Social Security Administration projection of total benefit payments for years after 2004 . This projection incorporates Social Security's intermediate economic and demographic assumptions, with one exception: the productivity growth rate is assumed to equal 0.75 percent.

The SSASS reports average benefits by age and sex by type of benefit as well as the total number of recipients in each age-sex category. These data were used to form population-weighted per capita OASDI benefit profiles by age and sex. Relative profiles of OASDI benefits for each year from 1960 through 1990 were obtained from that year's SSASS. For years after 1990 we use the 1990 relative profile of Social Security benefits by age and sex. 


\section{Medicare and Medicaid Benefits}

Aggregate Medicare and Medicaid payments from the inceptions of these programs through 1992 are those reported by NIPA. OMB provided us with unpublished projections on a NIPA basis of aggregate Medicare payments for the years 1993 through 2004. For the years between 2004 and 2030 we extrapolated aggregate Medicare payments using HCFA's $2004-2030$ projected Medicare growth rates. In the case of Medicaid we applied HCFA's projected annual Medicaid growth rates between 1993 and 2030 to the 1992 aggregate NIPA value of Medicaid. Medicare and Medicaid payments beyond 2030 are assumed to grow in accordance with demographic change and our assumed productivity growth rate. Relative profiles of Medicare and Medicaid benefits are based on HCFA data on average benefits by age and sex. In the case of Medicare, the data are available only by five-year age groups.

Unemployment Insurance, Aid to Families with Dependent Children, Food Stamps and General Welfare Benefits

Aggregate values of these federal, state, and local transfers are reported by NIPA. Supplemental security income as well as transfers for employment and training are distributed according to the relative profile for AFDC. General welfare benefits include federal black lung benefits, state general assistance, state energy assistance, education benefits, and other federal, state, and local transfers. The aggregate amount of earned income tax credits is distributed according to the relative profile for food stamps. Profiles for unemployment insurance, food stamps, AFDC, and general welfare are computed from the 1983 SIPP. These relative profiles are used in conjunc- 
tion with year-specific population counts by age and sex to distribute their respective aggregate expenditures by age and sex for all of the years between 1960 and 1992. For future years we assume that the age- and sex-specific values of each of these different types of transfer payments keep pace with productivity growth.

\section{Labor Income Taxes}

Aggregate federal, state, and local income taxes for 1960 through 1992 are those reported by the NIPA. For 1992 through 2004 we use OMB's projections of federal income tax revenues. State and local income taxes for 1993 through 2004 are projected using OMB's GDP forecast and assuming that the same ratio of state and local income taxes to GDP prevails between 1993 and 2004 as that which prevailed in 1992.

Aggregate labor income taxes in each year are calculated as the product of total federal, state, and local income taxes and labor's share of national income. We distribute aggregate labor income taxes based on the CPS profiles of labor income described above. After 2004 we assume that age- and sexspecific values of labor income taxes keep pace with productivity growth.

\section{Payro11 Taxes}

The NIPA reports aggregate values of payroll taxes from 1960 through 1992. OMB provided us with projections of aggregate federal payroll taxes from 1993 through 2004. Aggregate state and local payroll taxes for 1993 through 2004 were calculated based on OMB's projection of GDP between 1993 and 2004 and the assumption that the 1992 ratio of state and local payroll taxes to GDP prevails through 2004. Aggregate payroll taxes in the years 1960-2004 
are distributed by age and sex according to 1963-1992 CPS profiles of covered earnings, where covered earnings refers to labor earnings that are subject to Social Security payroll taxes. ${ }^{10}$ Age- and sex-specific values of payroll taxes beyond 2004 are assumed to equal their 2004 values adjusted for growth.

\section{Excise and Sales Taxes}

The NIPA is our source for aggregate excise tax (including property tax) and sales tax revenue from 1960 through 1992. For the period 1993-2004 we use OMB projections of federal excise and sales tax revenues. State and local excise and sales tax revenues between 1993 and 2004 are calculated using the 1992 ratio of these revenues to GDP and applying OMB's GDP forecasts through 2004 .

Relative age-sex profiles of excise and sales taxes were calculated from the $1960-61,1972-73,1984-86$, and 1987-90 CES. Separate profiles were constructed for tobacco, alcohol, property taxes, and all other sales and excise taxes. The 1960-61 profiles were used for years prior to 1966 . The 1972-73 profiles were used for the years 1967 through 1978. The 1984-86 profiles were used for the years 1979 through 1986, and the 1987-90 profiles were used for 1987 and beyond. Age- and sex-specific values of sales and excise taxes beyond 2004 are assumed to equal the 2004 values adjusted for growth.

\section{Capital Income Taxes}

10 Unfortunately, the data do not permit the calculation of separate profiles for state and local payroll taxes, which are not necessarily subject to earnings ceilings. However, non-Social Security payroll taxes are a small fraction of the total (less than 30 percent), so the bias associated with using Social Security covered earnings profiles is likely to be small. 
Aggregate capital income taxes between 1960 and 2004 are calculated as capital's share of national income multiplied by actual or projected values of aggregate federal, state, and local income tax revenues. Relative profiles of capital income taxes come from the 1962 and 1983 SCFs. These profiles are based upon weighted average net worth holdings by age and sex, where the weights applied are SCF person weights. This procedure could be applied only to individuals aged 80 or less because of limited data for older individuals. The profile of average net worth holdings by age and sex was smoothed and extrapolated through age 90 using a fourth-order polynomial. Age- and sexspecific values of capital income taxes after 2004 are assumed to equal the 2004 values, adjusted for growth.

Nonhuman Wealth

Age- and sex-specific values of nonhuman wealth (NHW) in each year between 1960 and 1992 are constructed by distributing by age and sex each year's level of total private net wealth. Aggregate private net wealth for these years is reported in the FOF. 11 The relative profiles of wealth holdings by age and sex are calculated by using data from the 1963 and 1983 SCF. In estimating the relative profiles, components of wealth that are owned jointly by members of a multi-person household are divided equally among such members. The 1963 profiles are used for years prior to 1963, and the 1983 profiles are used for years after 1983. The profiles for intermediate years are constructed by linearly interpolating between the 1963 and 1983 profiles.

${ }^{11}$ Our aggregates are net of the FOF's estimate of the value of residential structures, plant, and equipment owned by nonprofit institutions. Moreover, private sector pension reserves are netted out of FOF's private net worth since pension wealth is estimated separately. 


\section{The Term Value of Life Insurance}

Aggregate face values of life insurance for the years 1960 through 1992 are reported by the ACLI. The 1962 and 1983 SCF are used to distribute these amounts by age and sex. Fortunately, the SCFs report term as well as face values of life insurance. Consequently, we were able to calculate the ratio of term value to face value of 11 fe insurance on an age- and sex-specific basis for the years 1962 and 1983. Multiplying these ratios by our calculated age- and sex-specific face values of insurance produced age- and sex-specific term values of insurance for 1962 and 1983, and, after interpolating, for other years as well. 12

\section{Findings}

A. Changes in the Cohort Distribution of Resources

\section{Tota1 Resources}

The total resources of a cohort is the sum of its human, nonhuman, and pension wealth, less its generational account. Generational account refer to the present value of a sex-specific generation's future tax payments net of the present value of its future receipts of transfer payments. Our calculations include all tax payments made to, and transfer payments received from, federal, state, and local governments.

Tables $2 a$ and $2 b$ contain per capita values of total real resources and resource components for male and female cohorts in 10-year age groups for the years $1960,1970,1980$, and 1990 . The tables also show the per capita

12 Note that the cash value of life insurance is counted as part of nonhuman wealth. 
resources of all cohorts aged 20-89 and of older cohorts aged 65-89. For the entire populations of males and females, total resources grew substantially over the three decades since 1960, but they grew more rapidly for the elderly and for women. For males as a group, per capita resources rose by 45.4 percent. For older males, they grew by 113.0 percent. For females as a group, per capita resources rose by 129.0 percent. For older females, they grew by 120.3 percent. Between 1960 and 1990 female per capita resources rose from 38 percent to 61 percent of male per capita resources.

Some of the reported differences across ages and sex in resource growth are particularly striking. For example, males aged 20-29 experienced only a 17.2 percent increase in their average resources over the 30 years, whereas males aged 60-69 experienced a 119.1 percent increase, and females aged 20-29 experienced a 170.1 percent increase.

The relative growth in elderly Americans' resources appears primarily to reflect government intergenerational redistribution coupled with improvements in their longevity. Between 1960 and 1990 the generational account of older males fell from $-\$ 3,900$ to $-\$ 87,700$. The decline was even larger for older females. Their average generational account was $-\$ 7,300$ in 1960 , but in 1990 it was $-\$ 109,700$. Over the same period the generational accounts of younger cohorts rose dramatically. For example, the accounts of males aged 20-29 rose from $\$ 146,600$ to $\$ 195,800$ and those of females aged $20-29$ rose from $\$ 65,500$ to $\$ 117,900$. The components of generational accounts shown in tables $3 a$ and $3 b$ clearly indicate that the changes in the relative values of generational accounts of the old and the young primarily reflect increases in Social Security and government-provided health-care benefits (Medicare and Medicaid), on the one hand, and increases in labor income and payroll taxation, on the other. 
The relative growth in females' resources primarily reflects their increased participation in the labor force. According to Tables $2 a$ and $2 b$, in 1960 the human wealth of females aged 20-29 was $\$ 148,800$ per capita - just 28 percent of the corresponding male value of $\$ 520,500$. In 1990 the per capita human wealth of females in this age range was $\$ 348,000-56$ percent of the 1990 male average of $\$ 622,800$.

\section{The Composition of Total Resources}

Tables $4 \mathrm{a}$ and $4 \mathrm{~b}$ show the composition of total resources. For younger cohorts of both sexes, human wealth represents the bulk of resources. The reason is simply that most of their working years lie in the future. In fact, these cohorts' human wealth is larger than their total resources because the latter are calculated net of their positive generational accounts. In contrast, older cohorts' total resources are predominantly held in the form of nonhuman wealth. Over the three decades the share of human wealth in total resources declined for all male cohorts over 40 . The same is true for female cohorts aged 50 and over.

For the male population as a whole, the share of nonhuman wealth in total resources remained roughly constant, but it declined significantly for male cohorts over 65 years of age. For females, the share of nonhuman wealth declined for the population as a whole, and it declined significantly for women over 65 . The decline from 84 to 45 percent in the share of nonhuman wealth for older females was greater than the decline from 73 to 47 percent for older males.

As Tables $4 \mathrm{a}$ and $4 \mathrm{~b}$ indicate, private pension wealth is a small but growing component of total resources. Its share of total resources increased 
from 11 to 20 percent for older males and from 6 to 10 percent for older females. The share of resources represented by generational accounts also changed significantly over the three decades. Generational accounts as a share of total resources increased for males aged 39 or less, but declined significantly for females in the same age categories. For older males the excess, in present value, of future transfers over future taxes (the negative of the generational account) made up more than a quarter of total resources in 1990, compared with only 2 percent in 1960. The corresponding female figures are 43 percent in 1990 and 6 percent in 1960.

Tables $5 a$ and $5 b$ express the components of generational accounts as shares of total resources. Among other things, they show that health benefits rose from a minor share of elderly Americans' resources in 1960 to 17 percent of older males' resources and 28 percent of older females' resources in 1990.

\section{B. Changes in Bequeathable and Annuitized Resources}

Tables $6 \mathrm{a}$ and $6 \mathrm{~b}$ present the components of bequeathable resources nonhuman wealth plus the term value of life insurance - as well as the difference between bequeathable resources and total resources. This difference is annuitized resources. Tables $7 a$ and $7 b$ report these components as a fraction of total resources. The degree of resource annuitization, $R^{a}$, is computed as the ratio of annuitized to total resources, i.e.:

$$
\mathrm{R}^{\mathrm{a}}=1-\frac{\mathrm{TERM}+\mathrm{NHW}}{\mathrm{HW}+\mathrm{NHW}+\mathrm{PW}-\mathrm{GA}}
$$

where TERM stands for the average term value of life insurance, HW stands for average human wealth, NHW stands for average nonhuman wealth, PW stands for average private pension wealth, and GA stands for the generational account. 
Table 7a shows that $\mathrm{R}^{\mathrm{a}}$ has more than doubled for older males -- for cohorts aged 65 and older, it increased from 0.23 in 1960 to 0.51 in 1990 . For older female cohorts the increase reported in Table $7 \mathrm{~b}$ is even larger from 0.13 in 1960 to 0.54 in 1990 . This larger annuitized share of elderly persons' resources implies, of course, an equal and opposite decline in their share of bequeathable resources.

The increased annuitization of older males is offset by the decreased annuitization of younger males. Even though the increase in $R^{a}$ is small for younger males, they outnumber older ones. Hence, overall male resource annuitization is 74 percent in 1990 - the same as it was in 1960. For females, however, the ratio of annuitized to total resources increases for all age cohorts. For the female population as a whole, $\mathrm{R}^{\mathrm{a}}$ rises from 0.34 to 0.59 during this period.

\section{Sensitivity Analysis}

The calculations reported earlier assume a 1.2 percent rate of productivity growth $(g)$ and a discount rate $(r)$ of 6 percent. We denote these as the base case values for $r$ and $g$. Table 8 examines the sensitivity of $R^{a}$ to alternative discount rate assumptions. ${ }^{13}$ As the table shows, the conclusion that the resource annuitization of the elderly has increased dramatically since 1960 holds for a wide range of values of $r$. Higher interest rates produce smaller values of annuitized resources, but they do so for each of the years considered. Hence, the result that $\mathrm{R}^{\mathrm{a}}$ rises siginficantly over time is not affected by much.

${ }^{13}$ The effects of varying the rate of productivity growth were insignificant and are not reported. 
As mentioned, projected health benefits are an important component of annuitized resources for the elderly and the middle-aged. Table 9 examines the degree to which $\mathrm{R}^{\mathrm{a}}$ would be different under an alternative assumption regarding future government health-care policy. The policy (columns 3 and 4 in table 9) limits growth in real government health-care spending to the amount warranted by demographic change and labor productivity growth starting in 1996. Compared with the base case, this policy does not significantly alter the degree of annuitization for the elderly. Under the base case, 54 percent of the resources of older females are annuitized in 1990, compared with 51 percent under the stabilization policy. For older males, the respective figures are 51 percent and 49 percent. Thus, the post-1960 increase in annuitization remains dramatic despite stabilizing health care spending beginning in 1996.

\section{Implications for Aggregate Bequests and National Saving}

As discussed earlier, cohorts with higher degrees of annuitization will, ceteris paribus, bequeath less and consume more. To assess the impact on aggregate bequests of changes since 1960 in Americans' degree of annuitization, we first estimate the total flow of bequests in 1990 for base-case values of $r$ and $g$. We do so by multiplying the aggregate 1990 values of bequeathable wealth (net worth plus term life insurance) for individual male and female cohorts by their respective 1990 mortality probabilities. Summing the products over all cohorts yields an aggregate 1990 bequest flow of $\$ 207.5$ billion. Next, we calculate 1990 aggregate bequests under the assumption that a cohort's bequeathable resources in 1990 equal its total resources in 1990 multiplied by its 1960 ratio of bequeathable resources to total resources. 
This produces a 1990 bequest flow of $\$ 343.8$ billion for the base case. Thus, without the post-1960 increase in resource annuitization, aggregate 1990 bequests would have been an estimated 65.6 percent larger, holding, as we are in this counterfactual experiment, the total resources of each cohort fixed. The $\$ 136.3$ billion difference between these two bequest amounts constitutes the additional amount that generations alive in 1990 appear likely to have consumed as a consequence of this increased annuitization. This $\$ 136.3$ billion figure is substantial. It represents 87 percent of total net national saving in 1990 !

Table 10 indicates that the percentage reduction in estimated 1990 bequests due to the increased resource annuitization would not be much affected even if health-care spending were stabilized in 1994. Under this policy, the reduction in bequests would still be a sizable 58 percent. Table 11 examines the sensitivity of the reduction in bequests under alternative assumptions for $r$. Even for a value of $r$ as large as 9.0 percent, the reduction in bequests is 56.1 percent.

A different question about the reliability of these findings involves our use of the random bequest method to estimate the flow of bequests. This method assumes that the net worth and life insurance holdings of those people who actually die at age $x$ at time $t$ do not differ systematically with respect to their wealth holdings and 1 ife insurance from those who don't actually die at age $x$ at time $t$.

Admittedly, many of those who actually die at age $x$ at time $t$ may know ahead of time that they are about to die and spend down some of their assets through extravant spending. In addition, those that actually do die may incur particularly large uninsured medical expenses. But this bias in the random 
death method's calculation of bequests, whatever its size, is a bias that holds for each our calculations of actual bequests in 1990 as well as the hypothetical bequests that would have prevailed in 1990 had the degree of annuitization been that of 1960 . Indeed, if one assumes that end-of-1ife uninsured medical expenses and as well as end-of-life excess consumption in 1990 would have been the same had Americans' annuitization been that of 1960 , our procedure underestimates the percentage decline in bequests. 14

\section{Conclusion}

This paper combines a large array of micro and macro data to study changes since 1960 in the degree of annuitization of Americans' resources. Although we find no increase in the annuitization of younger Americans, we find a dramatic increase in the degree of annuitization of older Americans. This finding is robust to alternative assumptions about interest and growth rates as well as various possible courses of future U.S. health-care policy.

The increase in the annuitization of the elderly reflects increases in their receipt of Social Security and health transfers coupled with their failure to increase their purchase of life insurance. Since the elderly have much higher mortality probabilities, their degree of annuitization is critical to the flow of bequests. According to our base case estimates, holding fixed the total resources of each cohort, current aggregate U.S. bequests would be two thirds as much larger if these resources, particularly those of older Americans resources, were annuitized to the same degree as they were in 1960. In addition, U.S. national saving would likely be almost twice as large.

14 The reason is that the difference in bequests is the same, but the level of actual 1990 bequests is smaller, producing a larger percentage change in bequests in the hypothetical exercise. 


\section{References}

Abe1, Andrew B., "Precautionary Savings and Accidental Bequests, "American Economic Review, vo1. 75, no. 4, 1985, pp. 777-91.

Auerbach, Alan J., Jagadeesh Gokhale, and Laurence Kotlikoff, "Generational Accounting: A Meaningful Alternative to Deficit Accounting," Tax Policy and the Economy, ed. by David Bradford, National Bureau of Economic Research, vol. 5,1991, pp. 55-110.

Auerbach, Alan J., Laurence J. Kotlikoff, David N. Weil, "The Increasing Annuitization of the Elderly - Estimates and Implications for Intergenerational Transfers, Inequality, and National Saving," National Bureau of Economic Research working paper no. 4182, October 1992.

Boskin, Michael, Michael Knetter, and Laurence J. Kotlikoff, "Changes in the Age Distribution of Income in the United States, 1968-1984," mimeo, Center for Economic Policy Research, Stanford University, October 1985.

Davies, James, "Uncertain Lifetimes, Consumption and dissaving in Retirement," Journal of Political Economy, vol. 89, 1981, pp. 561-77.

Feldstein, Martin S., "Social Security, Induced Retirement, and Aggregate Capital Accumulation," Journal of Political Economy, vo1. 82, 1974, pp. 90526 .

Gokhale, Jagadeesh, Laurence J. Kotlikoff, and John Sabelhaus, "Understanding the Postwar Decline in U.S. Saving: A Cohort Analysis," Boston University, Department of Economics, mimeo 1994.

Kotlikoff, Laurence J., John shoven, and Avia Spivak, "The Impact of Annuity Insurance on Savings and Inequality," Journal of Labor Economics, vol. 4, no. 3, pt. 2, 1986, pp. 5183-207.

Park, Thae S., "Total Private Pension Benefit Payments, 1950-88, " Trends in Pensions, 1992", ed. by John A. Turner and Daniel J. Beller, U.S. Department of Labor, Pension and Welfare Benefits Administration, 1992, pp. 271-83.

Shyrock, Henry, S., and Jacob S. Seigel and Associates, The Methods and Materials of Demography, U.S. Department of Commerce, Bureau of the Census, vol. 1, 1971, pp. 365-6.

Yaari, Menahem, E. "Uncertain Lifetime, Life Insurance, and the Theory of the Consumer," Review of Economic Studies, vo1. 32, Apri1 1965, pp. 137-50. 
Table 1

Consumption of the Elderly Relative to the Young

Comparison

Male 70/Male 30

Female $70 /$ Male 30

Male 70/Female 30

Female 70/Female 30 $\underline{1960-61}$

.672

.667

.664

.659 $\underline{1972-73}$

.802

.798

.763

.760 $\underline{1984-86}$

1.135

1.045

1.059

.975 $\underline{1987-90}$

1.247

1.112

1.202

1.072

Source: Authors' calculations. 
Table 2a

Total Resources and Resource Components - Male Cohorts 1960-90

(Population Heighted Averages in Thousands of 1992 Dollars)

Age Group: $\quad 20-29 \quad 30-39 \quad 40-49 \quad 50-59 \quad 60-69 \quad 70-79 \quad 80-89 \quad 20-89 \quad 65-89$

TOTAL RESOURCES

$\begin{array}{llllllllll}1960 & 410.0 & 416.9 & 370.5 & 282.3 & 201.0 & 149.1 & 102.5 & 336.9 & 156.6 \\ 1970 & 432.3 & 476.0 & 449.9 & 374.8 & 273.0 & 198.3 & 118.1 & 395.2 & 204.6 \\ 1980 & 435.4 & 503.2 & 500.5 & 448.6 & 359.5 & 262.3 & 179.8 & 437.4 & 276.2 \\ 1990 & 480.7 & 533.7 & 552.9 & 516.7 & 440.5 & 323.7 & 176.2 & 489.7 & 333.5 \\ \text { X Increase } & & & & & & & & & \\ 1990 / 1960 & 17.2 & 28.0 & 49.2 & 83.1 & 119.1 & 117.1 & 71.9 & 45.4 & 113.0\end{array}$

HUMAN WEALTH

$\begin{array}{llllllllll}1960 & 520.5 & 475.1 & 357.1 & 202.4 & 65.6 & 13.4 & 6.0 & 331.8 & 21.6 \\ 1970 & 560.4 & 547.6 & 417.1 & 238.7 & 69.8 & 11.9 & 4.2 & 374.7 & 19.4 \\ 1980 & 564.7 & 570.3 & 439.3 & 248.5 & 66.6 & 10.6 & 3.2 & 395.9 & 18.3 \\ 1990 & 622.8 & 611.8 & 490.0 & 265.3 & 71.0 & 14.5 & 5.3 & 435.5 & 22.2 \\ \begin{array}{l}\text { X Increase } \\ 1990 / 1960\end{array} & 19.7 & 28.8 & 37.2 & 31.0 & 8.3 & 8.0 & -11.5 & 31.2 & 2.8\end{array}$

NON-HUMAN MEALTH

$\begin{array}{lrrrrrrrrr}1960 & 11.5 & 42.7 & 78.7 & 107.9 & 121.7 & 114.7 & 89.1 & 68.6 & 114.5 \\ 1970 & 12.0 & 45.8 & 93.4 & 133.6 & 151.4 & 133.0 & 78.3 & 79.4 & 131.8 \\ 1980 & 15.7 & 57.7 & 112.6 & 156.7 & 176.1 & 163.3 & 118.5 & 90.7 & 161.7 \\ 1990 & 15.0 & 51.2 & 109.7 & 164.9 & 187.2 & 158.5 & 74.5 & 90.0 & 155.7 \\ \begin{array}{l}\text { X Increase } \\ 1990 / 1960\end{array} & 30.5 & 20.0 & 39.3 & 52.8 & 53.8 & 38.2 & -16.3 & 31.3 & 35.9\end{array}$

PENSION WEALTH

$\begin{array}{lrrrrrrrrr}1960 & 24.6 & 31.6 & 32.8 & 24.9 & 21.7 & 15.2 & 7.0 & 26.7 & 16.5 \\ 1970 & 29.9 & 41.1 & 53.8 & 52.1 & 37.9 & 25.5 & 14.4 & 40.7 & 27.1 \\ 1980 & 32.9 & 47.4 & 67.4 & 84.4 & 72.5 & 37.1 & 21.1 & 53.7 & 44.1 \\ 1990 & 38.6 & 54.9 & 79.0 & 105.9 & 102.0 & 61.5 & 28.6 & 66.8 & 67.9 \\ \begin{array}{l}\text { X Increase } \\ 1990 / 1960\end{array} & 57.3 & 73.7 & 140.5 & 325.8 & 369.2 & 304.7 & 305.4 & 150.1 & 311.1\end{array}$

GENERATIONAL ACCOUNT

\begin{tabular}{rrrrrrrrrr}
1960 & 146.6 & 132.6 & 98.2 & 53.0 & 7.9 & -5.8 & -0.4 & 90.2 & -3.9 \\
1970 & 170.0 & 158.4 & 114.5 & 49.6 & -13.9 & -27.9 & -21.2 & 99.6 & -26.3 \\
1980 & 177.9 & 172.2 & 118.8 & 41.1 & -44.2 & -51.4 & -37.1 & 102.8 & -52.1 \\
1990 & 195.8 & 184.2 & 125.7 & 19.4 & -80.3 & -89.2 & -67.8 & 102.5 & -87.7 \\
\hline
\end{tabular}

Source: Authors' calculations. 
Table $2 b$

Total Resources and Resource Components - Female Cohorts 1960-90

(Population Weighted Averages in Thousands of 1992 Dollars)

Age Group: $\quad \begin{array}{lllllllll}20-29 & 30-39 & 40-49 & 50-59 & 60-69 & 70-79 & 80-89 & 20-89 & 65-89\end{array}$

TOTAL RESOURCES

$\begin{array}{lrrrrrrrrr}1960 & 97.9 & 111.8 & 152.0 & 166.4 & 144.2 & 112.0 & 86.1 & 129.4 & 117.0 \\ 1970 & 167.7 & 171.8 & 195.6 & 215.8 & 212.4 & 156.4 & 81.5 & 183.5 & 158.4 \\ 1980 & 216.0 & 243.2 & 273.9 & 286.2 & 275.3 & 222.7 & 160.9 & 246.3 & 223.6 \\ 1990 & 264.6 & 299.4 & 324.4 & 340.5 & 347.1 & 265.8 & 129.8 & 296.4 & 257.8 \\ \begin{array}{l}\text { X Increase } \\ 1990 / 1960\end{array} & 170.1 & 167.8 & 113.4 & 104.6 & 140.8 & 137.3 & 50.8 & 129.0 & 120.3 \\ & & & & & & & & & \\ \text { HUMAN HEALTH } & & & & & & & & & \\ 1960 & & & & & & & & & \\ 1970 & 148.8 & 120.6 & 98.6 & 60.4 & 17.3 & 2.9 & 0.5 & 87.4 & 5.2 \\ 1980 & 228.7 & 173.3 & 123.8 & 71.9 & 20.8 & 2.8 & 0.7 & 121.2 & 5.0 \\ 1990 & 294.6 & 255.2 & 169.3 & 82.0 & 20.8 & 3.0 & 0.8 & 166.1 & 5.0 \\ \text { X Increase } & 348.0 & 316.1 & 237.7 & 114.5 & 25.7 & 4.5 & 1.4 & 208.3 & 6.6 \\ 1990 / 1960 & 133.9 & 162.0 & 141.0 & 89.5 & 48.6 & 54.4 & 150.3 & 138.3 & 26.9\end{array}$

NON-HUMAN WEALTH

$\begin{array}{lrrrrrrrrr}1960 & 6.9 & 41.2 & 88.4 & 113.6 & 109.5 & 96.1 & 85.1 & 69.3 & 98.0 \\ 1970 & 12.2 & 53.0 & 97.4 & 129.5 & 136.9 & 106.6 & 52.8 & 79.5 & 105.9 \\ 1980 & 11.0 & 57.6 & 124.4 & 161.4 & 158.6 & 135.2 & 107.5 & 92.2 & 135.3 \\ 1990 & 20.8 & 66.5 & 109.9 & 152.4 & 169.6 & 122.5 & 29.9 & 90.2 & 115.3 \\ \begin{array}{l}\text { X Increase } \\ 1990 / 1960\end{array} & 201.0 & 61.2 & 24.3 & 34.1 & 54.9 & 27.5 & -64.8 & 30.2 & 17.7\end{array}$

PENSION MEALTH

$\begin{array}{lrrrrrrrrr}1960 & 7.8 & 9.8 & 10.1 & 11.3 & 10.3 & 5.7 & 2.3 & 9.3 & 6.5 \\ 1970 & 9.4 & 13.2 & 17.0 & 17.4 & 17.3 & 10.9 & 5.3 & 13.8 & 11.8 \\ 1980 & 11.5 & 15.9 & 22.6 & 28.6 & 25.4 & 17.1 & 9.9 & 18.7 & 17.6 \\ 1990 & 13.7 & 18.9 & 26.8 & 36.8 & 37.6 & 25.0 & 15.7 & 24.0 & 26.1 \\ \begin{array}{l}\text { Increase } \\ 1990 / 1960\end{array} & 76.2 & 92.2 & 164.5 & 226.2 & 267.2 & 335.6 & 571.2 & 158.0 & 301.0\end{array}$

GENERATIONAL ACCOUNT

$\begin{array}{rrrrrrrrrr}1960 & 65.5 & 59.9 & 45.1 & 18.9 & -7.1 & -7.3 & 1.9 & 36.6 & -7.3 \\ 1970 & 82.6 & 67.7 & 42.7 & 3.1 & -37.3 & -36.1 & -22.7 & 31.0 & -35.7 \\ 1980 & 101.1 & 85.5 & 42.4 & -14.2 & -70.5 & -67.5 & -42.7 & 30.7 & -65.7 \\ 1990 & 117.9 & 102.1 & 50.0 & -36.9 & -114.1 & -113.8 & -82.9 & 26.2 & -109.7\end{array}$

Source: Authors' calculations. 
Table 3a

The Components of Generational Accounts - Male Cohorts 1960-90

(Population Weighted Averages in Thousands of 1992 Dollars)

$\begin{array}{lrrrrrrrrr}\text { Age Group: } & 20-29 & 30-39 & 40-49 & 50-59 & 60-69 & 70-79 & 80-89 & 20-89 & 65-89 \\ & & & & & & & & & \\ \text { LABOR INCOME TAXES } & & & & & & & & \\ 1960 & 61.3 & 54.5 & 39.7 & 21.7 & 6.9 & 1.4 & 0.6 & 37.8 & 2.3 \\ 1970 & 71.5 & 68.8 & 51.9 & 29.1 & 8.4 & 1.4 & 0.5 & 47.1 & 2.3 \\ 1980 & 75.4 & 75.4 & 57.9 & 33.0 & 9.0 & 1.4 & 0.4 & 52.6 & 2.5 \\ 1990 & 86.0 & 82.4 & 64.7 & 34.5 & 9.2 & 1.9 & 0.7 & 58.7 & 2.9\end{array}$

PAYROLL TAXES

$\begin{array}{llllllllll}1960 & 51.2 & 40.8 & 27.8 & 14.8 & 4.6 & 1.0 & 0.3 & 28.7 & 1.5 \\ 1970 & 70.3 & 61.5 & 43.8 & 24.1 & 6.9 & 1.2 & 0.4 & 42.8 & 2.0 \\ 1980 & 79.2 & 76.3 & 56.8 & 31.4 & 8.3 & 1.3 & 0.4 & 53.3 & 2.3 \\ 1990 & 89.2 & 85.4 & 67.3 & 36.3 & 9.5 & 1.9 & 0.7 & 61.0 & 3.0\end{array}$

INDIRECT TAXES

$\begin{array}{rrrrrrrrrr}1960 & 46.5 & 44.4 & 36.8 & 25.5 & 15.2 & 8.1 & 4.4 & 33.9 & 9.5 \\ 1970 & 51.2 & 50.7 & 42.8 & 31.8 & 19.9 & 11.3 & 6.7 & 39.3 & 12.8 \\ 1980 & 53.6 & 53.7 & 46.2 & 35.4 & 23.7 & 14.1 & 8.4 & 42.9 & 15.7 \\ 1990 & 61.3 & 60.8 & 53.7 & 40.9 & 28.2 & 17.6 & 9.4 & 49.5 & 19.1\end{array}$

CAPITAL INCOME TAXES

$\begin{array}{rrrrrrrrrr}1960 & 19.0 & 26.8 & 31.6 & 30.9 & 24.3 & 14.8 & 7.5 & 25.5 & 16.7 \\ 1970 & 20.2 & 28.1 & 32.5 & 31.8 & 26.6 & 17.6 & 8.5 & 26.3 & 18.8 \\ 1980 & 22.9 & 31.7 & 37.3 & 36.1 & 29.5 & 21.1 & 13.6 & 29.5 & 22.3 \\ 1990 & 26.7 & 36.3 & 43.6 & 42.8 & 33.2 & 19.3 & 7.0 & 34.0 & 21.3\end{array}$

SOCIAL SECURITY BENEFITS (OASDI)

$\begin{array}{llllllllll}1960 & 11.7 & 16.2 & 22.8 & 27.4 & 34.2 & 26.5 & 11.5 & 21.1 & 28.5 \\ 1970 & 13.9 & 20.5 & 29.1 & 43.0 & 53.0 & 41.4 & 25.0 & 29.4 & 43.4 \\ 1980 & 16.1 & 23.7 & 35.3 & 52.2 & 73.5 & 56.1 & 36.1 & 35.6 & 60.2 \\ 1990 & 18.8 & 27.3 & 41.0 & 63.1 & 85.7 & 70.5 & 45.4 & 42.0 & 72.3\end{array}$

HEALTH BENEFITS (Medicare and Medicaid)

$\begin{array}{rrrrrrrrrr}1960 & 12.9 & 11.8 & 10.4 & 9.5 & 7.1 & 3.8 & 1.3 & 10.2 & 4.4 \\ 1970 & 20.3 & 22.2 & 20.9 & 19.4 & 19.4 & 15.8 & 11.0 & 20.0 & 16.4 \\ 1980 & 27.9 & 32.7 & 36.9 & 36.9 & 37.1 & 30.2 & 22.0 & 32.8 & 31.4 \\ 1990 & 38.7 & 44.2 & 54.6 & 65.4 & 69.8 & 55.7 & 38.1 & 50.9 & 57.8\end{array}$

WELFARE BENEFITS

\begin{tabular}{lrllllllll}
1960 & 6.8 & 5.9 & 4.5 & 3.1 & 1.7 & 0.9 & 0.4 & 4.4 & 1.1 \\
1970 & 8.9 & 8.1 & 6.6 & 4.9 & 3.3 & 2.3 & 1.3 & 6.4 & 2.4 \\
1980 & 9.2 & 8.5 & 7.1 & 5.7 & 4.2 & 3.1 & 1.8 & 7.1 & 3.2 \\
1990 & 10.0 & 9.3 & 8.0 & 6.6 & 5.0 & 3.7 & 2.1 & 7.9 & 3.8 \\
\hline
\end{tabular}

Source: Authors' calculations. 
Table 3b

The Components of Generational Accounts - Female Cohorts 1960-90

(Population Weighted Averages in Thousands of 1992 Dollars)

Age Group: $\quad 20-29 \quad 30-39 \quad 40-49 \quad 50-59 \quad 60-69 \quad 70-79 \quad 80-89 \quad 20-89 \quad 65-89$

LABOR INCOME TAXES

$\begin{array}{lrrrrrrrrr}1960 & 17.8 & 14.1 & 11.1 & 6.5 & 1.8 & 0.3 & 0.1 & 10.1 & 0.5 \\ 1970 & 29.3 & 22.0 & 15.5 & 8.8 & 2.5 & 0.3 & 0.1 & 15.3 & 0.6 \\ 1980 & 39.3 & 33.7 & 22.2 & 10.9 & 2.8 & 0.4 & 0.1 & 22.0 & 0.7 \\ 1990 & 47.7 & 42.4 & 31.3 & 14.9 & 3.3 & 0.6 & 0.2 & 28.0 & 0.9\end{array}$

PAYROLL TAXES

$\begin{array}{rrrrrrrrrr}1960 & 18.4 & 14.0 & 10.4 & 5.7 & 1.5 & 0.2 & 0.1 & 9.9 & 0.4 \\ 1970 & 32.2 & 23.8 & 16.4 & 9.1 & 2.5 & 0.4 & 0.1 & 16.5 & 0.6 \\ 1980 & 43.7 & 37.6 & 24.8 & 11.9 & 3.0 & 0.4 & 0.1 & 24.5 & 0.7 \\ 1990 & 52.7 & 47.5 & 35.6 & 17.2 & 3.9 & 0.7 & 0.2 & 31.4 & 1.0\end{array}$

INDIRECT TAXES

$\begin{array}{rrrrrrrrrr}1960 & 45.7 & 42.6 & 35.1 & 25.0 & 14.9 & 8.4 & 4.4 & 31.9 & 9.4 \\ 1970 & 50.3 & 48.8 & 41.0 & 30.9 & 20.3 & 11.6 & 6.7 & 36.7 & 12.7 \\ 1980 & 52.7 & 52.4 & 44.6 & 34.1 & 24.1 & 14.8 & 8.8 & 40.2 & 15.6 \\ 1990 & 60.0 & 59.6 & 51.7 & 39.6 & 27.9 & 17.5 & 10.1 & 46.1 & 18.1\end{array}$

CAPITAL INCOME TAXES

$\begin{array}{rrrrrrrrrr}1960 & 20.5 & 28.3 & 32.7 & 31.7 & 23.9 & 12.8 & 7.4 & 26.0 & 15.0 \\ 1970 & 20.3 & 29.5 & 33.8 & 31.4 & 25.1 & 16.0 & 7.9 & 26.1 & 16.9 \\ 1980 & 23.3 & 31.3 & 37.9 & 35.9 & 26.4 & 17.3 & 12.6 & 28.4 & 18.3 \\ 1990 & 29.2 & 37.4 & 42.0 & 40.1 & 29.7 & 13.9 & 3.7 & 32.2 & 15.3\end{array}$

SOCIAL SECURITY BENEFITS (OASDI)

$\begin{array}{llllllllll}1960 & 11.7 & 16.9 & 25.1 & 33.6 & 37.1 & 22.7 & 7.7 & 23.0 & 25.3 \\ 1970 & 13.4 & 20.3 & 30.0 & 45.7 & 58.3 & 41.7 & 22.6 & 31.4 & 43.3 \\ 1980 & 15.2 & 22.7 & 34.9 & 53.3 & 73.4 & 58.1 & 35.4 & 37.0 & 58.2 \\ 1990 & 17.8 & 25.9 & 39.4 & 62.3 & 85.1 & 70.2 & 46.2 & 42.9 & 69.4\end{array}$

HEALTH BENEFITS (Medicare and Medicaid)

$\begin{array}{rrrrrrrrrr}1960 & 15.3 & 15.8 & 15.3 & 14.5 & 11.0 & 5.7 & 2.0 & 13.7 & 6.6 \\ 1970 & 21.7 & 26.5 & 28.2 & 28.0 & 27.3 & 21.1 & 13.9 & 25.2 & 21.6 \\ 1980 & 27.7 & 36.6 & 46.1 & 49.9 & 50.5 & 40.2 & 27.4 & 39.4 & 40.6 \\ 1990 & 35.7 & 46.6 & 63.8 & 81.8 & 90.4 & 73.6 & 49.1 & 59.3 & 73.0\end{array}$

WELFARE BENEFITS

$\begin{array}{lrrrrrrrrr}1960 & 9.9 & 6.4 & 3.7 & 2.0 & 1.2 & 0.6 & 0.3 & 4.6 & 0.7 \\ 1970 & 14.3 & 9.7 & 5.8 & 3.4 & 2.2 & 1.6 & 1.0 & 7.1 & 1.6 \\ 1980 & 15.0 & 10.2 & 6.2 & 3.8 & 2.8 & 2.1 & 1.4 & 7.9 & 2.1 \\ 1990 & 18.3 & 12.3 & 7.4 & 4.6 & 3.4 & 2.6 & 1.7 & 9.4 & 2.6\end{array}$

Source: Authors' calculations. 
Table 4a

The Composition of Total Resources

Male Cohorts $1960-90$

$\begin{array}{lllllllll}\text { Age Group: } \quad 20-29 & 30-39 & 40-49 & 50-59 & 60-69 & 70-79 & 80-89 & 20-89 & 65-89\end{array}$

HUMAN WEALTH

$\begin{array}{llllllllll}1960 & 1.27 & 1.14 & 0.96 & 0.72 & 0.33 & 0.09 & 0.06 & 0.98 & 0.14 \\ 1970 & 1.30 & 1.15 & 0.93 & 0.64 & 0.26 & 0.06 & 0.04 & 0.95 & 0.09 \\ 1980 & 1.30 & 1.13 & 0.88 & 0.55 & 0.19 & 0.04 & 0.02 & 0.91 & 0.07 \\ 1990 & 1.30 & 1.15 & 0.89 & 0.51 & 0.16 & 0.04 & 0.03 & 0.89 & 0.07\end{array}$

NON-HUMAN WEALTH

$\begin{array}{llllllllll}1960 & 0.03 & 0.10 & 0.21 & 0.38 & 0.61 & 0.77 & 0.87 & 0.20 & 0.73 \\ 1970 & 0.03 & 0.10 & 0.21 & 0.36 & 0.55 & 0.67 & 0.66 & 0.20 & 0.64 \\ 1980 & 0.04 & 0.11 & 0.22 & 0.35 & 0.49 & 0.62 & 0.66 & 0.21 & 0.59 \\ 1990 & 0.03 & 0.10 & 0.20 & 0.32 & 0.42 & 0.49 & 0.42 & 0.18 & 0.47\end{array}$

PENSION NEALTH

$\begin{array}{llllllllll}1960 & 0.06 & 0.08 & 0.09 & 0.09 & 0.11 & 0.10 & 0.07 & 0.08 & 0.11 \\ 1970 & 0.07 & 0.09 & 0.12 & 0.14 & 0.14 & 0.13 & 0.12 & 0.10 & 0.13 \\ 1980 & 0.08 & 0.09 & 0.13 & 0.19 & 0.20 & 0.14 & 0.12 & 0.12 & 0.16 \\ 1990 & 0.08 & 0.10 & 0.14 & 0.21 & 0.23 & 0.19 & 0.16 & 0.14 & 0.20\end{array}$

GENERATIONAL ACCOUNT

$\begin{array}{llllllllll}1960 & 0.36 & 0.32 & 0.26 & 0.19 & 0.04 & -0.04 & 0.00 & 0.27 & -0.02 \\ 1970 & 0.39 & 0.33 & 0.25 & 0.13 & -0.05 & -0.14 & -0.18 & 0.25 & -0.13 \\ 1980 & 0.41 & 0.34 & 0.24 & 0.09 & -0.12 & -0.20 & -0.21 & 0.24 & -0.19 \\ 1990 & 0.41 & 0.35 & 0.23 & 0.04 & -0.18 & -0.28 & -0.38 & 0.21 & -0.26\end{array}$

Source: Authors' calculations. 
Table $4 b$

The Composition of Totsl Resources

Female Cohorts $1960-90$

Age Group: $\quad 20-29 \quad 30-39 \quad 40-49 \quad 50-59 \quad 60-69 \quad 70-79 \quad 80-89 \quad 20-89 \quad 65-89$

HUMAN WEALTH

$\begin{array}{llllllllll}1960 & 1.52 & 1.08 & 0.65 & 0.36 & 0.12 & 0.03 & 0.01 & 0.68 & 0.04 \\ 1970 & 1.36 & 1.01 & 0.63 & 0.33 & 0.10 & 0.02 & 0.01 & 0.66 & 0.03 \\ 1980 & 1.36 & 1.05 & 0.62 & 0.29 & 0.08 & 0.01 & 0.00 & 0.67 & 0.02 \\ 1990 & 1.32 & 1.06 & 0.73 & 0.34 & 0.07 & 0.02 & 0.01 & 0.70 & 0.03\end{array}$

NON-HUMAN WEALTH

$\begin{array}{llllllllll}1960 & 0.07 & 0.37 & 0.58 & 0.68 & 0.76 & 0.86 & 0.99 & 0.54 & 0.84 \\ 1970 & 0.07 & 0.31 & 0.50 & 0.60 & 0.64 & 0.68 & 0.65 & 0.43 & 0.67 \\ 1980 & 0.05 & 0.24 & 0.45 & 0.56 & 0.58 & 0.61 & 0.67 & 0.37 & 0.61 \\ 1990 & 0.08 & 0.22 & 0.34 & 0.45 & 0.49 & 0.46 & 0.23 & 0.30 & 0.45\end{array}$

PENSION WEALTH

$\begin{array}{llllllllll}1960 & 0.08 & 0.09 & 0.07 & 0.07 & 0.07 & 0.05 & 0.03 & 0.07 & 0.06 \\ 1970 & 0.06 & 0.08 & 0.09 & 0.08 & 0.08 & 0.07 & 0.06 & 0.08 & 0.07 \\ 1980 & 0.05 & 0.07 & 0.08 & 0.10 & 0.09 & 0.08 & 0.06 & 0.08 & 0.08 \\ 1990 & 0.05 & 0.06 & 0.08 & 0.11 & 0.11 & 0.09 & 0.12 & 0.08 & 0.10\end{array}$

GENERATIONAL ACCOUNT

$\begin{array}{llllllllll}1960 & 0.67 & 0.54 & 0.30 & 0.11 & -0.05 & -0.06 & 0.02 & 0.28 & -0.06 \\ 1970 & 0.49 & 0.39 & 0.22 & 0.01 & -0.18 & -0.23 & -0.28 & 0.17 & -0.23 \\ 1980 & 0.47 & 0.35 & 0.15 & -0.05 & -0.26 & -0.30 & -0.27 & 0.12 & -0.29 \\ 1990 & 0.45 & 0.34 & 0.15 & -0.11 & -0.33 & -0.43 & -0.64 & 0.09 & -0.43\end{array}$

Source: Authors' calculations. 
Table 5a

The Components of Generational Accounts As a Share of Total Resources

Male Cohorts $1960-90$

Age Group: $\quad 20-29 \quad 30-39 \quad 40-49 \quad 50-59 \quad 60-69 \quad 70-79 \quad 80-89 \quad 20-89 \quad 65-89$

LABOR INCOME TAXES

$\begin{array}{llllllllll}1960 & 0.15 & 0.13 & 0.11 & 0.08 & 0.03 & 0.01 & 0.01 & 0.11 & 0.01 \\ 1970 & 0.17 & 0.14 & 0.12 & 0.08 & 0.03 & 0.01 & 0.00 & 0.12 & 0.01 \\ 1980 & 0.17 & 0.15 & 0.12 & 0.07 & 0.02 & 0.01 & 0.00 & 0.12 & 0.01 \\ 1990 & 0.18 & 0.15 & 0.12 & 0.07 & 0.02 & 0.01 & 0.00 & 0.12 & 0.01\end{array}$

PAYROLL TAXES

$\begin{array}{llllllllll}1960 & 0.12 & 0.10 & 0.07 & 0.05 & 0.02 & 0.01 & 0.00 & 0.09 & 0.01 \\ 1970 & 0.16 & 0.13 & 0.10 & 0.06 & 0.03 & 0.01 & 0.00 & 0.11 & 0.01 \\ 1980 & 0.18 & 0.15 & 0.11 & 0.07 & 0.02 & 0.01 & 0.00 & 0.12 & 0.01 \\ 1990 & 0.19 & 0.16 & 0.12 & 0.07 & 0.02 & 0.01 & 0.00 & 0.12 & 0.01\end{array}$

INDIRECT TAXES

$\begin{array}{llllllllll}1960 & 0.11 & 0.11 & 0.10 & 0.09 & 0.08 & 0.05 & 0.04 & 0.10 & 0.06 \\ 1970 & 0.12 & 0.11 & 0.10 & 0.08 & 0.07 & 0.06 & 0.06 & 0.10 & 0.06 \\ 1980 & 0.12 & 0.11 & 0.09 & 0.08 & 0.07 & 0.05 & 0.05 & 0.10 & 0.06 \\ 1990 & 0.13 & 0.11 & 0.10 & 0.08 & 0.06 & 0.05 & 0.05 & 0.10 & 0.06\end{array}$

CAPITAL INCOME TAXES

$\begin{array}{llllllllll}1960 & 0.05 & 0.06 & 0.09 & 0.11 & 0.12 & 0.10 & 0.07 & 0.08 & 0.11 \\ 1970 & 0.05 & 0.06 & 0.07 & 0.08 & 0.10 & 0.09 & 0.07 & 0.07 & 0.09 \\ 1980 & 0.05 & 0.06 & 0.07 & 0.08 & 0.08 & 0.08 & 0.08 & 0.07 & 0.08 \\ 1990 & 0.06 & 0.07 & 0.08 & 0.08 & 0.08 & 0.06 & 0.04 & 0.07 & 0.06\end{array}$

SOCIAL SECURITY BENEFITS (OASDI)

$\begin{array}{llllllllll}1960 & 0.03 & 0.04 & 0.06 & 0.10 & 0.17 & 0.18 & 0.11 & 0.06 & 0.18 \\ 1970 & 0.03 & 0.04 & 0.06 & 0.11 & 0.19 & 0.21 & 0.21 & 0.07 & 0.21 \\ 1980 & 0.04 & 0.05 & 0.07 & 0.12 & 0.20 & 0.21 & 0.20 & 0.08 & 0.22 \\ 1990 & 0.04 & 0.05 & 0.07 & 0.12 & 0.19 & 0.22 & 0.26 & 0.09 & 0.22\end{array}$

hEALTH BENEFITS (Medicare and Medicaid)

$\begin{array}{llllllllll}1960 & 0.03 & 0.03 & 0.03 & 0.03 & 0.04 & 0.03 & 0.01 & 0.03 & 0.03 \\ 1970 & 0.05 & 0.05 & 0.05 & 0.05 & 0.07 & 0.08 & 0.09 & 0.05 & 0.08 \\ 1980 & 0.06 & 0.06 & 0.07 & 0.08 & 0.10 & 0.12 & 0.12 & 0.07 & 0.11 \\ 1990 & 0.08 & 0.08 & 0.10 & 0.13 & 0.16 & 0.17 & 0.22 & 0.10 & 0.17\end{array}$

WELFARE BENEFITS

$\begin{array}{llllllllll}1960 & 0.02 & 0.01 & 0.01 & 0.01 & 0.01 & 0.01 & 0.00 & 0.01 & 0.01 \\ 1970 & 0.02 & 0.02 & 0.01 & 0.01 & 0.01 & 0.01 & 0.01 & 0.02 & 0.01 \\ 1980 & 0.02 & 0.02 & 0.01 & 0.01 & 0.01 & 0.01 & 0.01 & 0.02 & 0.01 \\ 1990 & 0.02 & 0.02 & 0.01 & 0.01 & 0.01 & 0.01 & 0.01 & 0.02 & 0.01\end{array}$

Source: Authors' calculations. 
Table 5b

The Components of Generational Accounts As a Share of Total Resources

Female Cohorts $1960-90$

$\begin{array}{lllllllll}\text { Age Group: } \quad 20-29 & 30-39 & 40-49 & 50-59 & 60-69 & 70-79 & 80-89 & 20-89 & 65-89\end{array}$

LABOR INCOME TAXES

$\begin{array}{llllllllll}1960 & 0.18 & 0.13 & 0.07 & 0.04 & 0.01 & 0.00 & 0.00 & 0.08 & 0.00 \\ 1970 & 0.17 & 0.13 & 0.08 & 0.04 & 0.01 & 0.00 & 0.00 & 0.08 & 0.00 \\ 1980 & 0.18 & 0.14 & 0.08 & 0.04 & 0.01 & 0.00 & 0.00 & 0.09 & 0.00 \\ 1990 & 0.18 & 0.14 & 0.10 & 0.04 & 0.01 & 0.00 & 0.00 & 0.09 & 0.00\end{array}$

PAYROLL TAXES

$\begin{array}{llllllllll}1960 & 0.19 & 0.12 & 0.07 & 0.03 & 0.01 & 0.00 & 0.00 & 0.08 & 0.00 \\ 1970 & 0.19 & 0.14 & 0.08 & 0.04 & 0.01 & 0.00 & 0.00 & 0.09 & 0.00 \\ 1980 & 0.20 & 0.15 & 0.09 & 0.04 & 0.01 & 0.00 & 0.00 & 0.10 & 0.00 \\ 1990 & 0.20 & 0.16 & 0.11 & 0.05 & 0.01 & 0.00 & 0.00 & 0.11 & 0.00\end{array}$

IND IRECT TAXES

$\begin{array}{llllllllll}1960 & 0.47 & 0.38 & 0.23 & 0.15 & 0.10 & 0.07 & 0.05 & 0.25 & 0.08 \\ 1970 & 0.30 & 0.28 & 0.21 & 0.14 & 0.10 & 0.07 & 0.08 & 0.20 & 0.08 \\ 1980 & 0.24 & 0.22 & 0.16 & 0.12 & 0.09 & 0.07 & 0.05 & 0.16 & 0.07 \\ 1990 & 0.23 & 0.20 & 0.16 & 0.12 & 0.08 & 0.07 & 0.08 & 0.16 & 0.07\end{array}$

CAPITAL IMCOME TAXES

$\begin{array}{llllllllll}1960 & 0.21 & 0.25 & 0.22 & 0.19 & 0.17 & 0.11 & 0.09 & 0.20 & 0.13 \\ 1970 & 0.12 & 0.17 & 0.17 & 0.15 & 0.12 & 0.10 & 0.10 & 0.14 & 0.11 \\ 1980 & 0.11 & 0.13 & 0.14 & 0.13 & 0.10 & 0.08 & 0.08 & 0.12 & 0.08 \\ 1990 & 0.11 & 0.12 & 0.13 & 0.12 & 0.09 & 0.05 & 0.03 & 0.11 & 0.06\end{array}$

SOCIAL SECURITY BENEFITS (OASDI)

$\begin{array}{llllllllll}1960 & 0.12 & 0.15 & 0.17 & 0.20 & 0.26 & 0.20 & 0.09 & 0.18 & 0.22 \\ 1970 & 0.08 & 0.12 & 0.15 & 0.21 & 0.27 & 0.27 & 0.28 & 0.17 & 0.27 \\ 1980 & 0.07 & 0.09 & 0.13 & 0.19 & 0.27 & 0.26 & 0.22 & 0.15 & 0.26 \\ 1990 & 0.07 & 0.09 & 0.12 & 0.18 & 0.25 & 0.26 & 0.36 & 0.14 & 0.27\end{array}$

HEALTH BENEFITS (Medicare and Medicaid)

$\begin{array}{llllllllll}1960 & 0.16 & 0.14 & 0.10 & 0.09 & 0.08 & 0.05 & 0.02 & 0.11 & 0.06 \\ 1970 & 0.13 & 0.15 & 0.14 & 0.13 & 0.13 & 0.14 & 0.17 & 0.14 & 0.14 \\ 1980 & 0.13 & 0.15 & 0.17 & 0.17 & 0.18 & 0.18 & 0.17 & 0.16 & 0.18 \\ 1990 & 0.14 & 0.16 & 0.20 & 0.24 & 0.26 & 0.28 & 0.38 & 0.20 & 0.28 \\ & & & & & & & & & \\ \text { WELLARE } & \text { 8ENEF ITS } & & & & & & & & \\ 1960 & 0.10 & 0.06 & 0.02 & 0.01 & 0.01 & 0.01 & 0.00 & 0.04 & 0.01 \\ 1970 & 0.09 & 0.06 & 0.03 & 0.02 & 0.01 & 0.01 & 0.01 & 0.04 & 0.01 \\ 1980 & 0.07 & 0.04 & 0.02 & 0.01 & 0.01 & 0.01 & 0.01 & 0.03 & 0.01 \\ 1990 & 0.07 & 0.04 & 0.02 & 0.01 & 0.01 & 0.01 & 0.01 & 0.03 & 0.01\end{array}$

Source: Authors' calculations. 
Table 6a

The Components of Bequeathable Resources -- Male Cohorts 1960-90

(Population Weighted Averages in Thousands of 1992 Dollars)

Age Group: $\quad 20-29 \quad 30-39 \quad 40-49 \quad 50-59 \quad 60-69 \quad 70-79 \quad 80-89 \quad 20-89 \quad 65-89$

TOTAL RESOURCES

$\begin{array}{llllllllll}1960 & 410.0 & 416.9 & 370.5 & 282.3 & 201.0 & 149.1 & 102.5 & 336.9 & 156.6 \\ 1970 & 432.3 & 476.0 & 449.9 & 374.8 & 273.0 & 198.3 & 118.1 & 395.2 & 204.6 \\ 1980 & 435.4 & 503.2 & 500.5 & 448.6 & 359.5 & 262.3 & 179.8 & 437.4 & 276.2 \\ 1990 & 480.7 & 533.7 & 552.9 & 516.7 & 440.5 & 323.7 & 176.2 & 489.7 & 333.5\end{array}$

NON-HUMAN WEALTH

$\begin{array}{rrrrrrrrrr}1960 & 11.5 & 42.7 & 78.7 & 107.9 & 121.7 & 114.7 & 89.1 & 68.6 & 114.5 \\ 1970 & 12.0 & 45.8 & 93.4 & 133.6 & 151.4 & 133.0 & 78.3 & 79.4 & 131.8 \\ 1980 & 15.7 & 57.7 & 112.6 & 156.7 & 176.1 & 163.3 & 118.5 & 90.7 & 161.7 \\ 1990 & 15.0 & 51.2 & 109.7 & 164.9 & 187.2 & 158.5 & 74.5 & 90.0 & 155.7\end{array}$

TERM VALUE OF LIFE INSURANCE

$\begin{array}{llllllllll}1960 & 17.6 & 25.7 & 24.3 & 18.1 & 10.4 & 4.5 & 1.6 & 19.0 & 5.7 \\ 1970 & 19.8 & 38.5 & 38.2 & 27.7 & 14.7 & 5.2 & 1.8 & 26.4 & 6.9 \\ 1980 & 26.5 & 41.0 & 39.3 & 28.9 & 16.4 & 6.8 & 2.3 & 29.1 & 8.5 \\ 1990 & 26.4 & 56.3 & 58.0 & 41.2 & 20.0 & 6.1 & 2.0 & 38.8 & 8.7\end{array}$

BEQUEATHABLE WEALTH (Non-Human Wealth plus Term Value of Life Insurance)

$\begin{array}{rrrrrrrrrr}1960 & 29.1 & 68.5 & 103.0 & 126.0 & 132.1 & 119.1 & 90.6 & 87.5 & 120.2 \\ 1970 & 31.9 & 84.3 & 131.5 & 161.4 & 166.1 & 138.1 & 80.1 & 105.7 & 138.7 \\ 1980 & 42.3 & 98.7 & 151.9 & 185.6 & 192.6 & 170.1 & 120.8 & 119.8 & 170.3 \\ 1990 & 41.4 & 107.5 & 167.7 & 206.0 & 207.2 & 164.6 & 76.5 & 128.8 & 164.4\end{array}$

ANNUITIZED WEALTH (Total Wealth minus Bequeathable Wealth)

$\begin{array}{rrrrrrrrrr}1960 & 380.9 & 348.4 & 267.4 & 156.2 & 69.0 & 30.0 & 11.8 & 249.4 & 36.4 \\ 1970 & 400.5 & 391.7 & 318.3 & 213.5 & 106.9 & 60.2 & 38.0 & 289.4 & 65.9 \\ 1980 & 393.1 & 404.5 & 348.6 & 262.9 & 166.9 & 92.3 & 59.0 & 317.6 & 105.9 \\ 1990 & 439.3 & 426.2 & 385.2 & 310.7 & 233.3 & 159.1 & 99.7 & 360.9 & 169.2\end{array}$

Source: Authors' calculations. 
Table 6b

The Components of Bequeathable Resources - Female Cohorts 1960-90

(Population Weighted Averages in Thousands of 1992 Dollars)

Age Group: $\quad 20-29 \quad 30-39 \quad 40-49 \quad 50-59 \quad 60-69 \quad 70-79 \quad 80-89 \quad 20-89 \quad 65-89$

TOTAL RESOURCES

$\begin{array}{rrrrrrrrrr}1960 & 97.9 & 111.8 & 152.0 & 166.4 & 144.2 & 112.0 & 86.1 & 129.4 & 117.0 \\ 1970 & 167.7 & 171.8 & 195.6 & 215.8 & 212.4 & 156.4 & 81.5 & 183.5 & 158.4 \\ 1980 & 216.0 & 243.2 & 273.9 & 286.2 & 275.3 & 222.7 & 160.9 & 246.3 & 223.6 \\ 1990 & 264.6 & 299.4 & 324.4 & 340.5 & 347.1 & 265.8 & 129.8 & 296.4 & 257.8\end{array}$

NON-HUMAN WEALTH

$\begin{array}{rrrrrrrrrr}1960 & 6.9 & 41.2 & 88.4 & 113.6 & 109.5 & 96.1 & 85.1 & 69.3 & 98.0 \\ 1970 & 12.2 & 53.0 & 97.4 & 129.5 & 136.9 & 106.6 & 52.8 & 79.5 & 105.9 \\ 1980 & 11.0 & 57.6 & 124.4 & 161.4 & 158.6 & 135.2 & 107.5 & 92.2 & 135.3 \\ 1990 & 20.8 & 66.5 & 109.9 & 152.4 & 169.6 & 122.5 & 29.9 & 90.2 & 115.3\end{array}$

TERM VALUE OF LIFE INSURANCE

$\begin{array}{lrllllllll}1960 & 18.4 & 24.2 & 21.1 & 14.4 & 7.3 & 2.7 & 1.3 & 16.6 & 3.6 \\ 1970 & 20.8 & 35.4 & 32.2 & 21.2 & 9.4 & 2.5 & 0.9 & 21.9 & 3.6 \\ 1980 & 27.8 & 38.6 & 33.9 & 22.7 & 11.3 & 3.9 & 1.8 & 25.0 & 5.0 \\ 1990 & 27.1 & 50.8 & 48.4 & 30.7 & 11.8 & 2.2 & 0.4 & 31.4 & 3.5\end{array}$

BEQUEATHABLE WEALTH (Non-Human Weal th plus Term Value of Life Insurance)

$\begin{array}{rrrrrrrrrr}1960 & 25.3 & 65.5 & 109.5 & 128.0 & 116.8 & 98.8 & 86.4 & 85.9 & 101.6 \\ 1970 & 33.0 & 88.4 & 129.6 & 150.7 & 146.3 & 109.1 & 53.7 & 101.5 & 109.5 \\ 1980 & 38.8 & 96.2 & 158.3 & 184.1 & 169.9 & 139.1 & 109.3 & 117.1 & 140.3 \\ 1990 & 47.8 & 117.3 & 158.3 & 183.1 & 181.4 & 124.7 & 30.4 & 121.7 & 118.9\end{array}$

ANMUITIZED WEALTH (Total Wealth minus Bequeathable Weal th)

$\begin{array}{rrrrrrrrrr}1960 & 72.6 & 46.3 & 42.5 & 38.4 & 27.4 & 13.2 & -0.3 & 43.5 & 15.4 \\ 1970 & 134.7 & 83.5 & 65.9 & 65.1 & 66.1 & 47.3 & 27.8 & 82.1 & 48.9 \\ 1980 & 177.2 & 147.1 & 115.6 & 102.1 & 105.4 & 83.6 & 51.6 & 129.2 & 83.2 \\ 1990 & 216.8 & 182.0 & 166.1 & 157.4 & 165.7 & 141.1 & 99.5 & 174.7 & 138.9\end{array}$

Source: Authors' calculations. 
Table 7a

Bequeathable and Annuitized Resources As a Share of Total Resources

Male Cohorts $1960-90$

Age Group: $\quad 20-29 \quad 30-39 \quad 40-49 \quad 50-59 \quad 60-69 \quad 70-79 \quad 80-89 \quad 20-89 \quad 65-89$

TOTAL RESOURCES

$\begin{array}{llllllllll}1960 & 1.00 & 1.00 & 1.00 & 1.00 & 1.00 & 1.00 & 1.00 & 1.00 & 1.00 \\ 1970 & 1.00 & 1.00 & 1.00 & 1.00 & 1.00 & 1.00 & 1.00 & 1.00 & 1.00 \\ 1980 & 1.00 & 1.00 & 1.00 & 1.00 & 1.00 & 1.00 & 1.00 & 1.00 & 1.00 \\ 1990 & 1.00 & 1.00 & 1.00 & 1.00 & 1.00 & 1.00 & 1.00 & 1.00 & 1.00\end{array}$

MON-HUMAN HEALTH

$\begin{array}{llllllllll}1960 & 0.03 & 0.10 & 0.21 & 0.38 & 0.61 & 0.77 & 0.87 & 0.20 & 0.73 \\ 1970 & 0.03 & 0.10 & 0.21 & 0.36 & 0.55 & 0.67 & 0.66 & 0.20 & 0.64 \\ 1980 & 0.04 & 0.11 & 0.22 & 0.35 & 0.49 & 0.62 & 0.66 & 0.21 & 0.59 \\ 1990 & 0.03 & 0.10 & 0.20 & 0.32 & 0.42 & 0.49 & 0.42 & 0.18 & 0.47\end{array}$

TERM VALUE OF LIFE INSURANCE

$\begin{array}{llllllllll}1960 & 0.04 & 0.06 & 0.07 & 0.06 & 0.05 & 0.03 & 0.02 & 0.06 & 0.04 \\ 1970 & 0.05 & 0.08 & 0.08 & 0.07 & 0.05 & 0.03 & 0.01 & 0.07 & 0.03 \\ 1980 & 0.06 & 0.08 & 0.08 & 0.06 & 0.05 & 0.03 & 0.01 & 0.07 & 0.03 \\ 1990 & 0.05 & 0.11 & 0.10 & 0.08 & 0.05 & 0.02 & 0.01 & 0.08 & 0.03\end{array}$

Bequeathable mealth (Non-Human Heal th plus Term Value of Life Insurance)

$\begin{array}{llllllllll}1960 & 0.07 & 0.16 & 0.28 & 0.45 & 0.66 & 0.80 & 0.88 & 0.26 & 0.77 \\ 1970 & 0.07 & 0.18 & 0.29 & 0.43 & 0.61 & 0.70 & 0.68 & 0.27 & 0.68 \\ 1980 & 0.10 & 0.20 & 0.30 & 0.41 & 0.54 & 0.65 & 0.67 & 0.27 & 0.62 \\ 1990 & 0.09 & 0.20 & 0.30 & 0.40 & 0.47 & 0.51 & 0.43 & 0.26 & 0.49\end{array}$

ANNUITIZED WEALTH (Total Weal th minus Bequeathable Wealth)

$\begin{array}{llllllllll}1960 & 0.93 & 0.84 & 0.72 & 0.55 & 0.34 & 0.20 & 0.12 & 0.74 & 0.23 \\ 1970 & 0.93 & 0.82 & 0.71 & 0.57 & 0.39 & 0.30 & 0.32 & 0.73 & 0.32 \\ 1980 & 0.90 & 0.80 & 0.70 & 0.59 & 0.46 & 0.35 & 0.33 & 0.73 & 0.38 \\ 1990 & 0.91 & 0.80 & 0.70 & 0.60 & 0.53 & 0.49 & 0.57 & 0.74 & 0.51\end{array}$

Source: Authors' calculations. 
Table $7 b$

Bequeathable and Annuitized Resources As a Share of Total Resources

Fenale Cohorts 1960-90

Age Group: $\quad 20-29 \quad 30-39 \quad 40-49 \quad 50-59 \quad 60-69 \quad 70-79 \quad 80-89 \quad 20-89 \quad 65-89$

TOTAL RESOURCES

$\begin{array}{lllllllllll}1960 & 1.00 & 1.00 & 1.00 & 1.00 & 1.00 & 1.00 & 1.00 & 1.00 & 1.00 \\ 1970 & 1.00 & 1.00 & 1.00 & 1.00 & 1.00 & 1.00 & 1.00 & 1.00 & 1.00 \\ 1980 & 1.00 & 1.00 & 1.00 & 1.00 & 1.00 & 1.00 & 1.00 & 1.00 & 1.00 \\ 1990 & 1.00 & 1.00 & 1.00 & 1.00 & 1.00 & 1.00 & 1.00 & 1.00 & 1.00\end{array}$

NON-HUMAN HEALTH

$\begin{array}{lllllllllll}1960 & 0.07 & 0.37 & 0.58 & 0.68 & 0.76 & 0.86 & 0.99 & 0.54 & 0.84 \\ 1970 & 0.07 & 0.31 & 0.50 & 0.60 & 0.64 & 0.68 & 0.65 & 0.43 & 0.67 \\ 1980 & 0.05 & 0.24 & 0.45 & 0.56 & 0.58 & 0.61 & 0.67 & 0.37 & 0.61 \\ 1990 & 0.08 & 0.22 & 0.34 & 0.45 & 0.49 & 0.46 & 0.23 & 0.30 & 0.45\end{array}$

TERM VALUE OF LIFE INSURANCE

$\begin{array}{llllllllll}1960 & 0.19 & 0.22 & 0.14 & 0.09 & 0.05 & 0.02 & 0.01 & 0.13 & 0.03 \\ 1970 & 0.12 & 0.21 & 0.16 & 0.10 & 0.04 & 0.02 & 0.01 & 0.12 & 0.02 \\ 1980 & 0.13 & 0.16 & 0.12 & 0.08 & 0.04 & 0.02 & 0.01 & 0.10 & 0.02 \\ 1990 & 0.10 & 0.17 & 0.15 & 0.09 & 0.03 & 0.01 & 0.00 & 0.11 & 0.01\end{array}$

BEQUEATHABLE WEALTH (Non-Human Wealth plus Term Value of Life Insurance)

$\begin{array}{llllllllll}1960 & 0.26 & 0.59 & 0.72 & 0.77 & 0.81 & 0.88 & 1.00 & 0.66 & 0.87 \\ 1970 & 0.20 & 0.51 & 0.66 & 0.70 & 0.69 & 0.70 & 0.66 & 0.55 & 0.69 \\ 1980 & 0.18 & 0.40 & 0.58 & 0.64 & 0.62 & 0.62 & 0.68 & 0.48 & 0.63 \\ 1990 & 0.18 & 0.39 & 0.49 & 0.54 & 0.52 & 0.47 & 0.23 & 0.41 & 0.46\end{array}$

ANNUITIZED WEALTH (Total Wealth minus Bequeathable Wealth)

$\begin{array}{llllllllll}1960 & 0.74 & 0.41 & 0.28 & 0.23 & 0.19 & 0.12 & 0.00 & 0.34 & 0.13 \\ 1970 & 0.80 & 0.49 & 0.34 & 0.30 & 0.31 & 0.30 & 0.34 & 0.45 & 0.31 \\ 1980 & 0.82 & 0.60 & 0.42 & 0.36 & 0.38 & 0.38 & 0.32 & 0.52 & 0.37 \\ 1990 & 0.82 & 0.61 & 0.51 & 0.46 & 0.48 & 0.53 & 0.77 & 0.59 & 0.54\end{array}$

Source: Authors' calculations. 
Table 8

Ratio of Annuitized to Total Resources under Different

Interest Rate ( $r$ ) Assumptions

$$
r=3.0 \times \quad r=6.0 \times \quad r=9.0 \times
$$

$\begin{array}{lllllll}\text { Males } & 20-89 & 65-89 & 20-89 & 65-89 & 20-89 & 65-89 \\ & & & & & & \\ 1960 & 0.82 & 0.28 & 0.74 & 0.23 & 0.67 & 0.20 \\ 1970 & 0.81 & 0.37 & 0.73 & 0.32 & 0.66 & 0.28 \\ 1980 & 0.82 & 0.44 & 0.73 & 0.38 & 0.64 & 0.34 \\ 1990 & 0.82 & 0.56 & 0.74 & 0.51 & 0.65 & 0.46\end{array}$

Females

$\begin{array}{lllllll}1960 & 0.56 & 0.19 & 0.34 & 0.13 & 0.18 & 0.09 \\ 1970 & 0.64 & 0.38 & 0.45 & 0.31 & 0.30 & 0.26 \\ 1980 & 0.69 & 0.44 & 0.52 & 0.37 & 0.39 & 0.31 \\ 1990 & 0.73 & 0.60 & 0.59 & 0.54 & 0.47 & 0.48\end{array}$

Source: Authors' calculations 
Table 9

Ratios of Annuitized to Total Resources under

Alternative Health Care Spending Outcones

Year

Base Case

Stabilizing

Heal th Care

Spending

After 1996

(1) (2)

(5) (6)

Males

20-89 65-89

$20-89 \quad 65-89$

1960

$0.74 \quad 0.23$

$\begin{array}{ll}0.74 & 0.23\end{array}$

1970

0.73

0.32

$0.73 \quad 0.32$

$0.73 \quad 0.38$

$0.72 \quad 0.38$
0.73

1990

$0.74 \quad 0.51$

$0.73 \quad 0.49$

Females

$\begin{array}{lllll}1960 & 0.34 & 0.13 & 0.32 & 0.13 \\ 1970 & 0.45 & 0.31 & 0.43 & 0.31 \\ 1980 & 0.52 & 0.37 & 0.50 & 0.37 \\ 1990 & 0.59 & 0.54 & 0.55 & 0.51\end{array}$

Source: Authors' calculations. 
Table 10

Annual Bequest Flow in 1990 Based upon Annuitization Ratios for 1990 and 1960

Alternative Health Care Spending Outcomes

(Billions of 1992 Dollars)

Base Case

Stabilizing

Health Care

Spending

After 1996

1960

343.8

328.8

ratio

1990

ratio

207.5

207.5

Percent

difference

65.6

58.4

Source: Authors' calculations. 
Table 11

Amual 1990 Bequest Flow Based upon Annuitization Ratios for 1990 and 1960

Alternative Interest Rate ( $r$ ) Assumptions

(Billions of 1992 dollars)

$r=0.03 \% \quad r=0.06 x \quad r=0.75 \%$

\section{Bequest}

Flows

1960

ratio

369.5

343.8

323.9

1990

ratio

207.5

207.5

207.5

Percent

difference

78.1

65.6

56.1

Source: Authors' calculations. 